Галасюк В. В., к.е.н. (Голова Комітету Верховної Ради України з питань промислової політики та підприємництва, Президент Української асоціації Римського Клубу), ORCID: 0000-0002-1617-326X

\title{
СПЕЦІАЛІЗАЦІЯ НАЦІОНАЛЬНОї ЕКОНОМІКИ ЯК ЗАСАДНИЧИЙ ФАКТОР ЕКОНОМІЧНОГО ЗРОСТАННЯ І ДОБРОБУТУ
}

Стаття розвиває дискусію щодо ролі та значущості різних чинників економічного зростання на рівні національного господарства. Розкрито вплив експортного кошику та виробничої спеціалізації країни на рівень ВВП країни та доходів громадян. Обґрунтовано, що спеціалізація на певних видах економічної діяльності є ключовим фактором прискорення економічного зростання та підвищення рівня добробуту суспільства. Аргументується, що ефективна економічна спеціалізація країни є визначальним фактором їі економічного зростання, і що вплив цього чинника суттєво вагоміший навіть за такі важливі фактори, як інституційне середовище, якість і доступність освіти, розвиток інфраструктури, верховенство права та політична стабільність. Запропоновано критерії оцінки «якості» видів економічної діяльності в контексті формування ефективної економічної спеціалізації країни. Розроблено ієрархію видів економічної діяльності для формування ефективної економічної політики структурної модернізації та прискорення зростання національної економіки. Визначено принцип диференціації державної політики по відношенню до різних видів економічної діяльності, в залежності від їх «якості» як джерел економічного зростання.

Ключові слова: економічна спеціалізація, структура економіки, фактори зростання, економічна складність, економічна політика.

Постановка проблеми. Масштабні проблеми безробіття, бідності та соціальної нерівності привертають все більшу увагу до механізмів забезпечення ефективних трансформацій соціально-економічних систем як на глобальній економічній арені, так і на національному рівні. Зокрема, актуалізуються проблеми чіткої ідентифікації головних детермінант економічного зростання та удосконалення механізмів їх цілеспрямованого використання для стимулювання економічного зростання країн, що розвиваються. Незважаючи на актуальність та значущість цих питань, спостерігається дефіцит відповідних знань як в теоретичному, так і в прикладному вимірі. Вітчизняна і світова 
наукова думка досі сповнені спірними, фрагментарними, а часом й відверто хибними уявленнями про те, завдяки чому та яким чином провідні економіки сучасності здобули економічне лідерство та кардинально підвищили добробут громадян. Проте загострення соціальних проблем та зростання економічної нерівності на світовій арені змушує країни, що відстають за рівнем добробуту, відкидати ідеологічні догми і шукати реальні, емпірично виправдані рецепти прискорення економічного зростання. У зв'язку з цим набуває значної актуальності вивчення засадничих чинників економічного зростання та розробка механізмів їх цілеспрямованого використання для підвищення добробуту суспільства.

Аналіз останніх досліджень і публікацій. Науковій дискусії 3 визначення основоположних факторів економічного зростання країн присвячено публікації низки як вітчизняних (колектив ДУ «Інститут економіки та прогнозування НАН України» на чолі з І.М. Бабух [1], О. Кендюхов та К. Ягельська [2], О.В. Шкурупій та Н.Г. Базавлук [3], А.С. Магдіч [4], І.Ю. Штулер [5]), так і зарубіжних (Ф.Т. Болдану [6], Д. Во [7], А. Бассаніні [8], Д. Аджемоглу [9]) вчених. Зокрема, науковий доробок зазначених авторів присвячено висвітленню питань типологізації факторів економічного зростання, еволюції наукових поглядів на систему цих факторів, систематизації основних підходів до їх класифікації тощо.

Виділення невирішених раніше частин загальної проблеми. Віддаючи належне вагомому науковому доробку вчених-економістів щодо чинників економічного зростання, слід зазначити, що засадничо-важливому фактору - економічній спеціалізації країни - досі присвячено вкрай недостатню увагу. Існуючим напрацюванням бракує усвідомлення засадничої ролі та особливої значущості цього фактору, його місця в системі інших чинників, що впливають на місце національних економік у міжнародному поділі праці, а також системного бачення механізмів цілеспрямованого використання цього фактору як важеля для прискорення економічного зростання. Це обумовлює гостру актуальність поглиблення наукової дискусії у даному напрямі.

Методологія дослідження. У процесі дослідження були використані як загальнонаукові, так і спеціальні методи наукового пізнання, серед яких: метод компаративного аналізу при визначенні рівня впливу та взаємозв'язку між окремими чинниками економічного зростання; метод системно-структурного аналізу при визначенні критеріїв оцінювання якості окремих видів економічної діяльності як предмета економічної спеціалізації. Крім того, використано методи класифікації, групування та графічного зображення результатів. 
Метою статті $\epsilon$ обґрунтування твердження про те, що саме економічна спеціалізація слугує ключовим драйвером розвитку національних господарських систем та лежить в основі становлення решти факторів, які визначають добробут країн і перспективи його зростання, що окремі види економічної діяльності $€$ більш корисними для прискорення економічного зростання і підлягають культивуванню через стимулюючу економічну політику, а інші гальмують економічне зростання і економічна політика щодо них має суттєво відрізнятись.

Виклад основного матеріалу. В кожної країни $є$ своя «професія» або економічна спеціалізація. Вона визначається тими видами господарської діяльності, що домінують в структурі економіки та формують основну частину національного доходу. У першому наближенні економічна спеціалізація визначається структурою експортних поставок. Наприклад, за даними Світового Банку, 79\% експорту $€_{\text {в- }}$ росоюзу - продукція переробної промисловості. Водночас, близько $70 \%$ українського експорту - сировина необроблена або з найменшим рівнем обробки [10]. Таким чином, спеціалізація країн ЄС полягає у виробництві, тоді як України - в постачанні сировинних ресурсів (мінеральних ресурсів, сільськогосподарської сировини, простих напівфабрикатів тощо). На моє глибоке переконання, саме в цьому полягає причина п'ятикратного відставання України від ЄС за рівнем ВВП на душу населення і, відповідно, за рівнем доходів громадян.

Справа в тому, що вартість сировини зазвичай $є$ в рази нижчою за вартість готової продукції. Це чітко простежується 3 порівняння цін на сировину, яку Україна експортує, та на готову продукцію, яка ввозиться нею з-закордону. Головний парадокс полягає в тому, що ця імпортна продукція нерідко вироблена в інших країнах саме з української сировини та ще й українцями - вимушеними трудовими емігрантами. В результаті за кордоном створюються робочі місця і додана вартість, розвивається промисловість і економіка, там сплачуються податки та високі заробітні плати. А Україна натомість отримує збиток від міжнародної торгівлі, слабшу промисловість, залежність від зовнішніх запозичень та масову еміграцію.

До речі, українська металургія - не менш яскрава ілюстрація важливості економічної спеціалізації. Металобрухт, який використовується як один з видів сировини усіма металургійними підприємствами, коштує близько $\$ 320 /$ т. На нього, як і на український ліскругляк, існує величезний попит за кордоном. Адже виплавка сталі 3 його використанням більш економічно ефективна та екологічно чиста. Очевидно, що країні не вигідно масово вивозити закордон таку цінну промислову сировину. Особливо, якщо врахувати, що вартість вагонів, цистерн і аналогічної металопродукції на порядок переви- 
щує ціну металобрухту. Саме тому для ліквідації дефіциту металобрухту як сировини для українських металургійних підприємств Верховною Радою України протягом 2015-2019 років було майже в 6 разів підвищено вивізне мито на експорт металобрухту. Це дозволило скоротити дефіцит металобрухту для національної промисловості 3 9\% до 2\% та відповідно суттєво підвищити глибину переробки і надходження до бюджету [11].

Як парадоксально би це не звучало, проте навіть широко знана в світі українська IT-індустрія $\epsilon$ переважно сировинною. Адже вона як мінімум на 80\% працює за моделлю аутсорсингу, продаючи людино-години українських програмістів, а не ліцензії на IT-програми чи технології. Річний експорт ІТ-послуг приносить Україні понад \$4 млрд, генеруючи майже $3 \%$ ВВП. Але ці цифри можна збільшити в рази за рахунок формування інноваційної екосистеми, переорієнтації IT-індустрії з аутсорсингової на продуктову модель, стимулювання внутрішнього попиту на інновації. Додатковий ефект вітчизняна ITіндустрія здатна принести як каталізатор продуктивності в аграрному секторі та промисловості при масштабному застосуванні її інноваційних IT-рішень на внутрішньому ринку.

Разом з цим, для наукової думки надзвичайно важливо, що засадниче значення спеціалізації як рушія економічного розвитку простежується не лише на основі вивчення кейс-стаді та економічної історії, а й у результаті провідних емпіричних досліджень сучасних науковців. Зокрема, професори Хаусманн (Гарвардський університет) та Ідальго (MIT) довели, що Індекс Складності Економіки (Economic Complexity Index), який за своєю суттю відображає економічну спеціалізацію та технологічний рівень країни, має на порядок більший вплив на економічне зростання з-поміж усіх інституційних чинників, таких як політична стабільність, верховенство права, якість врядування, контроль корупції тощо. Індекс Складності Економіки, по суті індикатор якості «професії» країни, також в 5 разів сильніше корелює з економічним зростанням ніж усі освітні показники чи навіть комплексний індекс конкурентоздатності економіки Всесвітнього економічного форуму (ВЕФ) у довгостроковій перспективі [12].

Це означає, що багато країн, в яких гірше інституційне середовище, менш якісна освіта чи не настільки розвинута інфраструктура, незважаючи на відставання за цими факторами, суттєво випереджають Україну в економічному розвитку через більш ефективну економічну спеціалізацію, технологічний рівень, структуру економіки. Тому розповсюджені поради щодо необхідності спершу подолати корупцію, побудувати інститути, забезпечити політичну стабільність, 
реформувати освіту, піднятись в міжнародних рейтингах тощо $є$ не більш ніж міфами й ідеологічними штампами, що культивуються тими, кому вони в силу певних причин вигідні. Як бачимо, наукові доробки, побудовані на реальних фактах і закономірностях, засвідчують протилежне.

Це означає, що багато країн, в яких гірше інституційне середовище, менш якісна освіта чи не настільки розвинута інфраструктура, незважаючи на відставання за цими факторами, суттєво випереджають Україну в економічному розвитку через більш ефективну економічну спеціалізацію, технологічний рівень, структуру економіки. Тому розповсюджені поради щодо необхідності спершу подолати корупцію, побудувати інститути, забезпечити політичну стабільність, реформувати освіту, піднятись в міжнародних рейтингах тощо $\epsilon$ не більш ніж міфами й ідеологічними штампами, що культивуються тими, кому вони в силу певних причин вигідні. Як бачимо, наукові доробки, побудовані на реальних фактах і закономірностях, засвідчують протилежне.

Своїм дослідженням Хаусманн та Ідальго підтвердили висновки, яких дійшов професор Райнерт в результаті аналізу економічної політики та економічної історії різних країн світу за понад 500 років. Зокрема про те, що різні види економічної діяльності якісно відрізняються як джерела добробуту. Створена ними модель показала, що для 128 країн, щодо яких є достатні дані для аналізу, економічна складність пояснює 73\% варіації ВВП на душу населення (з поправкою на доходи від видобутку корисних копалин, який залежить від геології, а не від ноу-хау).

Визнання вирішального значення «професії» країни (по суті, структури економіки з домінуванням певних видів діяльності), $\epsilon$ поворотним моментом в еволюції економічної теорії та підставою для докорінного перегляду економічної політики України та багатьох країн, що опинились в схожій економічній ситуації.

Отже, спеціалізація на одних видах економічної діяльності та продуктах з часом приносить добробут, а на інших - бідність. Розвиваючи вишукування Антоніо Серра більш ніж 400-річної давнини, Райнерт наголошує, що «в багатих країнах ми, як правило, спостерігаємо недосконалу конкуренцію і економічну діяльність зі зростаючою віддачею» і що «усі багаті країни забагатіли однаковим способом, використовуючи одну й ту саму стратегію, - вони відмовились від сировинних товарів та спадаючою віддачею заради обробної промисловості і зростаючої віддачі» [13].

Райнерт підкреслює: ідея про те, що спеціалізація виробництва визначає інституційний поступ, не $є$ новою: «У 1620 році Френсіс Бе- 
кон сформулював точку зору, яка превалювала в науковій спільності протягом двох наступних сторіч: $€$ величезна різниця «між життям людей в якомусь найбільш культурному краю Європи і в якійсь найбільш дикій та варварській області Нової Індії... І відбувається це не від землі, не від клімату, не від статури, а від наук». Бекон чітко розумів причинно-наслідковий зв'язок: діяльність людини, тобто їі спосіб виробництва, визначає їі інститути. Торстейн Веблен, один з засновників старої інституційної школи, також підкреслював, що «щоденна діяльність - причина створення інститутів, а не навпаки» [14].

Таким чином, існує величезна різниця між виробництвом й науковими дослідженнями та видобутком корисних копалин й сільським господарством. I величезне значення має що саме виробляти та експортувати - пшеницю, кукурудзу, яблука, руду, ліс-кругляк чи літаки, кораблі, автомобілі, станки, ліки, програмне забезпечення, продукти харчування, хімічну продукцію. Для того, щоб проранжувати різні види економічної діяльності за рівнем корисності для суспільства, Райнерт виділяє два принципово відмінних типи економічної діяльності - Шумпетерові та Мальтусові. Спираючись на його підхід, а також беручи до уваги ще й екологічні і соціальні чинники, можна запропонувати такі критерії оцінки «якості» видів економічної діяльності (таблиця).

Спираючись на зазначені критерії, базова ієрархія видів економічної діяльності може бути представлена так (рисунок).

Якщо у певного виду діяльності чи індустрії наявні принаймні 23 ознаки з правої колонки таблиці, інші ознаки цієї колонки напевно супроводжуватимуть їх також. Якщо в галузі спостерігається спадна віддача з високим ступенем ймовірності, вона пов'язана з вичерпанням природних ресурсів та спричиняє значний «екологічний відбиток». Досконала (цінова) конкуренція призводить до зменшення заробітних плат та скорочення людського капіталу. Низький рівень оплати праці $€$ «супутником» низького технологічного рівня та, відповідно, низького рівня синергії з іншими видами діяльності.

Таблиця

Критерії оцінки «якості» видів економічної діяльності

\begin{tabular}{|l|l|}
\hline \multicolumn{1}{|c|}{ «Якісні» види діяльності } & \multicolumn{1}{|c|}{ «Неякісні» види діяльності } \\
\hline Зростаюча віддача & Спадна віддача \\
Недосконала (нецінова) конкуренція & Досконала (цінова) конкуренція \\
Високий технологічний рівень & Низький технологічний рівень \\
Багато зв'язків, висока синергія & Мало зв'язків, низька синергія \\
Не вичерпують природні ресурси & Вичерпують природні ресурси \\
Незначний «екологічний відбиток» & Значний «екологічний відбиток» \\
\hline
\end{tabular}




\begin{tabular}{|l|l|}
\hline $\begin{array}{l}\text { Кваліфікована та високооплачувана } \\
\text { праця }\end{array}$ & $\begin{array}{l}\text { Некваліфікована й низькооплачува- } \\
\text { Нарощення людського капіталу }\end{array}$ \\
\hline
\end{tabular}

Джерело: укладено автором мічна галузь, машинобудування, фармацевтична індустрія

Сервісні та креативні індустрії:

IT, дизайн, медіа-продакшн

Металургійна промисловість низьких переділів, застаріла важка та легка промисловість, харчова промисловість

\section{Наука і «хай-тек»}

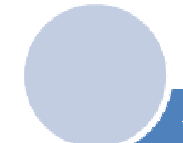

$Q$ Дослідження і розробки

Інтелөктуальномістк ө нематеріельне виребництве

9

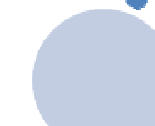

Висекетохнелагічне метеріальне

- виробництво

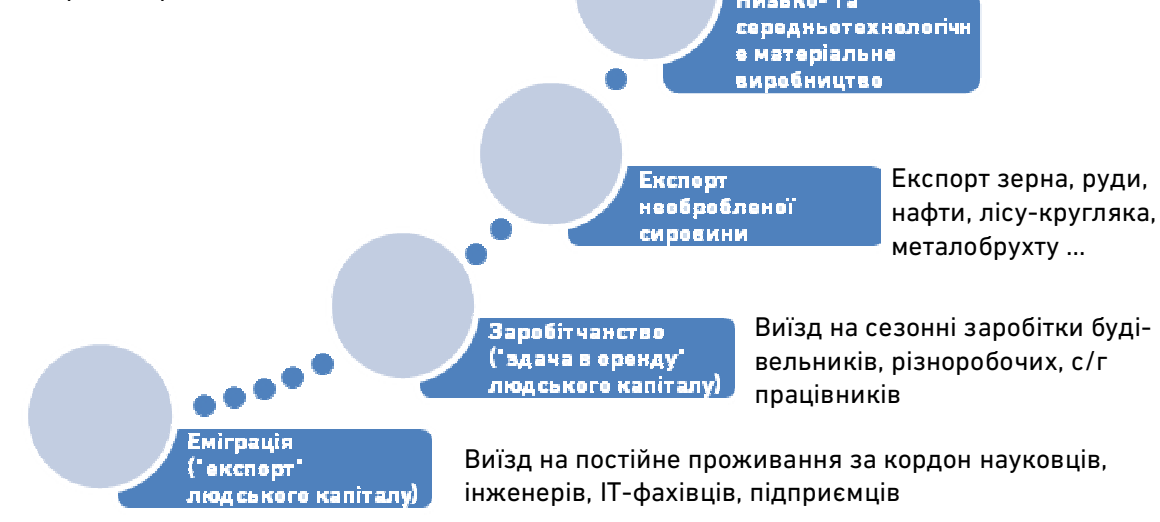

Рисунок. Базова ієрархія видів економічної діяльності Джерело: укладено автором

У лівій колонці таблиці простежується аналогічна логіка. Якщо ми бачимо зростаючу віддачу, це означає, що немає прямої прив'язки до вичерпання природних ресурсів. Це може свідчити і про менший «екологічний відбиток» такої діяльності. Якщо рівень оплати праці високий, це $\epsilon$ опосередкованою ознакою високотехнологічності та недосконалої (нецінової) конкуренції, бо в іншому випадку роботодавець не зміг би собі цього дозволити. Наявність бага- 
тьох зв'язків з іншими індустріями та відповідні синергетичні ефекти з іншими видами діяльності йдуть пліч-о-пліч з високим рівнем кваліфікації та оплати праці і, відповідно, з нарощуванням людського капіталу.

Держава не може й у жодному разі не повинна ставитись до якісно різних видів діяльності як до рівних. Адже вони кардинально відрізняються як драйвери економічного зростання та соціального розвитку. Лише деякі види діяльності здатні вивести країну на нову орбіту. Вони економічно, соціально й екологічно більш бажані для країни і суспільства, тому повинні визнаватись пріоритетними та всіляко підтримуватися. До видів діяльності, що знаходяться на найнижчих сходинках ієрархії, має бути зовсім інше ставлення.

Висновки. Темпи економічного зростання залежать від «професії» країни, її економічної спеціалізації, яка по суті проявляється у виробничій структурі національного господарства. Саме економічна спеціалізація значно переважає такі чинники, як інституційне середовище, якість і доступність освіти, розвиток інфраструктури, верховенство права та політична стабільність, і $€$ засадничою детермінантою економічного зростання країни в майбутньому, особливо в довгостроковій перспективі. Існує принципова різниця між різними видами економічної діяльності як джерелами економічного зростання. Держава має застосовувати стимулюючу економічну політику до найбільш корисних видів діяльності, які $€$ «прискорювачами» економічного зростання, та нейтральну чи навіть обмежувальну політику по відношенню до інших видів діяльності. Така диференціація економічної політики забезпечить структурну модернізацію та прискорене зростання національної економіки і, відповідно, реальне збільшення доходів громадян.

1. Національні та глобальні детермінанти економічного зростання України : наукова доповідь / за ред. д.е.н. І.М. Бобух; НАН України, ДУ «Ін-т екон. та прогнозув. НАН України». К., 2018. 390 с. 2. Кендюхов О., Ягельска К. Чинники випереджаючого економічного розвитку. Вісник економічної науки України. 2013. № 2. С. 47-51. 3. Шкурупій О. В., Базавлук Н. Г. Чинники динаміки економіки України та національної конкурентоспроможності. Проблеми економіки. 2014. № 2. С. 89-94. 4. Магдіч А. С. Типологія факторів економічного зростання: теоретико-методологічний аспект. Європейський вектор економічного розвитку. 2015. № 2(19). С. 119-130. 5. Штулер І. Ю. Еволюція теорій економічного розвитку у сучасному вимірі знань. Глобальні та національні проблеми економіки. 2016. Вип. 9. С. 216-219. 6. Boldeanu F. T., Constantinescu L. The main determinants affecting economic growth. Bulletin 
of the Transilvania University of Braşov Series. V: Economic Sciences. 2015. Vol. 8(57). No. 2. 7. Vo D. What Factors Affect Income Inequality and Economic Growth in Middle-Income Countries? / D. Vo, T. C. Nguyen, N. P. Tran et al. Journal of Risk and Financial Management. 2019. Vol. 12. Issue 1. P. 40-51. 8. Bassanini A., Scarpetta S. The Driving Forces of Economic Growth: Panel Data Evidence for The OECD Countries. URL: https://www.oecd.org/eco/growth/18450995.pdf. (дата звернення: 15.03.2019). 9. Acemoglu D. Introduction to modern economic growth. Princeton : Princeton University Press, 2009. 1008 p. 10. Manufactures exports (\% of merchandise exports). The World Bank Data. URL: https://data.worldbank.org/indicator/TX. VAL.MANF.ZS.UN?view=chart. (дата звернення: 15.03.2019). 11. Аналітичні дані / Сайт Об'єднання підприємств «Укрметалургпром». URL: http://www.ukrmetprom.org/analitichni-dani. (дата звернення: 15.03.2019). 12. Hausmann R., Hidalgo C. A. The Atlas of Economic Complexity Mapping Paths to Prosperity. URL: https://atlas.media.mit.edu/static/pdf/atlas/AtlasOfEconomicComplexity_Part _l.pdf. (дата звернення: 15.03.2019). 13. Reinert E. S. How Rich Countries Got Rich and Why Poor Countries Stay Poor. London : Constable \& Robinson, 2007. 14. Reinert E. S., Reinert A. S. Mercantilism and Economic Development: Schumpeterian Dynamics, Institution-building and International Benchmarking. The Origins of Development Economics: How Schools of Economic Thoughts Have Addressed Development. London : Zed books, 2007. P. 1-24.

\section{REFERENCES:}

1. Natsionalni ta hlobalni determinanty ekonomichnoho zrostannia Ukrainy : naukova dopovid / za red. d.e.n. I.M. Bobukh; NAN Ukrainy, DU «In-t ekon. ta prohnozuv. NAN Ukrainy». K., 2018. 390 s. 2. Kendiukhov O., Yahelska K. Chynnyky vyperedzhaiuchoho ekonomichnoho rozvytku. Visnyk ekonomichnoi nauky Ukrainy. 2013. № 2. S. 47-51. 3. Shkurupii 0. V., Bazavluk N. H. Chynnyky dynamiky ekonomiky Ukrainy ta natsionalnoi konkurentospromozhnosti. Problemy ekonomiky. 2014. № 2. S. 89-94. 4. Mahdich A. S. Typolohiia faktoriv ekonomichnoho zrostannia: teoretyko-metodolohichnyi aspekt. Yevropeiskyi vektor ekonomichnoho rozvytku. 2015. № 2(19). S. 119-130. 5. Shtuler I. Yu. Evoliutsiia teorii ekonomichnoho rozvytku u suchasnomu vymiri znan. Hlobalni ta natsionalni problemy ekonomiky. 2016. Vyp. 9. S. 216-219. 6. Boldeanu F. T., Constantinescu L. The main determinants affecting economic growth. Bulletin of the Transilvania University of Braşov Series. V: Economic Sciences. 2015. Vol. 8(57). No. 2. 7. Vo D. What Factors Affect Income Inequality and Economic Growth in Middle-Income Countries? / D. Vo, T. C. Nguyen, N. P. Tran et al. Journal of Risk and Financial Management. 2019. Vol. 12. Issue 1. P. 40-51. 8. Bassanini A., Scarpetta S. The Driving Forces of Economic Growth: Panel Data Evidence for The OECD Countries. URL: https://www.oecd.org/eco/growth/18450995.pdf. (data zvernennia: 15.03.2019). 9. Acemoglu D. Introduction to modern economic growth. 
Princeton : Princeton University Press, 2009. 1008 p. 10. Manufactures exports (\% of merchandise exports). The World Bank Data. URL: https://data.worldbank.org/indicator/TX. VAL.MANF.ZS.UN?view=chart. (data zvernennia: 15.03.2019). 11. Analitychni dani / Sait Obiednannia pidpryiemstv «Ukrmetalurhprom». URL: http://www.ukrmetprom.org/analitichni-dani. (data zvernennia: 15.03.2019). 12. Hausmann R., Hidalgo C. A. The Atlas of Economic Complexity Mapping Paths to Prosperity. URL: https://atlas.media.mit.edu/static/pdf/atlas/AtlasOfEconomicComplexity_Part _l.pdf. (data zvernennia: 15.03.2019). 13. Reinert E. S. How Rich Countries Got Rich and Why Poor Countries Stay Poor. London : Constable \& Robinson, 2007. 14. Reinert E. S., Reinert A. S. Mercantilism and Economic Development: Schumpeterian Dynamics, Institution-building and International Benchmarking. The Origins of Development Economics: How Schools of Economic Thoughts Have Addressed Development. London : Zed books, 2007. P. 1-24.

Halasiuk V. V., Candidate of Economics (Ph.D.) (Chairman of the Parliamentary Committee on Industrial Policy and Entrepreneurship, President of the Ukrainian Association for the Club of Rome)

\section{SPECIALIZATION OF NATIONAL ECONOMY AS A FUNDAMENTAL DRIVER FOR ECONOMIC GROWTH AND WELFARE}

The Article starts up a discussion on the role and significance of varied factors for economic growth at the level of the national economy. The work explores how exports basket and specialization of national manufacture impacts national GDP and incomes of the population. It is substantiated that specialization in certain types of economic activity is a key factor to accelerate economic growth and raise the level of well-being of the society. The author provides arguments which prove the fact that efficient economic specialization of the country is a key criterion which determines its economic development; and the impact of this criterion is even more significant than such important factors as institutional environment, qualitative and accessible education, infrastructure development, rule of law, and political stability. The Article suggests a set of assessment criteria for the "quality" of economic activities in the context of creation the efficient economic specialization of the country. In the scientific work a hierarchy of types of economic activity was elaborated in order to create an efficient economic policy for structural modernization and acceleration of the national economic growth. The author determines the principle of differentiation of the state policy towards varied types 
of economic activity depending on their "quality" as sources of economic growth.

Keywords: economic specialization, economic structure, drivers for economic growth, economic complexity, economic policy.

Галасюк В. В., к.э.н. (Председатель Комитета Верховной Рады Украины по вопросам промышленной политики и предпринимательства, Президент Украинской ассоциации Римского Клуба)

\section{СПЕЦИАЛИЗАЦИЯ НАЦИОНАЛЬНОЙ ЭКОНОМИКИ КАК ОСНОВОПОЛАГАЮЩИЙ ФАКТОР ЭКОНОМИЧЕСКОГО РОСТА И БЛАГОПОЛУЧИЯ}

Статья развивает дискуссию о роли и значимости различных факторов экономического роста на уровне национального хозяйства. Раскрыто влияние экспортной корзины и производственной специализации страны на уровень ВВП страны и доходов граждан. Обосновано, что специализация на определенных видах экономической деятельности является ключевым фактором ускорения экономического роста и повышения уровня благосостояния общества. Аргументируется, что эффективная экономическая специализация страны является определяющим фактором ее экономического роста, и влияние этого фактора существенно значимым даже за такие важные факторы, как институциональная среда, качество и доступность образования, развитие инфраструктуры, верховенство права и политическая стабильность. Предложены критерии оценки «качества» видов экономической деятельности в контексте формирования эффективной экономической специализации страны. Разработан иерархию видов экономической деятельности для формирования эффективной экономической политики структурной модернизации и ускорения роста национальной экономики. Определен принцип дифференциации государственной политики по отношению к различным видам экономической деятельности, в зависимости от их «качества» как источников экономического роста. Ключевые слова: экономическая специализация, структура экономики, факторы роста, экономическая сложность, экономическая политика. 